胆管内への発育が顕著であった小結節型肝細胞癌の 1 切除例

\begin{tabular}{|c|c|c|c|c|c|c|c|}
\hline \multicolumn{8}{|c|}{ 東京女子医科大学消化器病センター外科 } \\
\hline 山本 & 雅一 & 高崎 & 健 & 武藤 & 晴臣 & 矢川 & 彰治 \\
\hline 有架 & 淳 & 林 & 俊之 & 清水 & 泰 & 斉藤 & 明子 \\
\hline 林 & 一郎 & 羽生 & 士夫 & & & & \\
\hline
\end{tabular}

\title{
A RESECTED CASE OF SMALL NODULAR HEPATOCELLULAR CARCINOMA CONSPICUOUSLY GROWING INTO THE BILE DUCT
}

\author{
Masakazu YAMAMOTO, Ken TAKASAKI, Haruomi MUTO, \\ Akiharu YAGAWA, Atsushi ARUGA, Toshiyuki HAYASHI, \\ Tai SHIMIZU, Akiko SAITO, Seiichiro KOBAYASHI \\ and Fujio HANYU
}

The Institute of Gastroenterology, Tokyo Women's Medical College

索引用語 : intraductal spreading hepatocellular carcinoma

はじめに

主腫瘍が肝表面近傍の小結節型腫瘍であるにもかか わらず，顕著な胆管内発育を呈した肝細胞癌の 1 切除 例を経験したので，考察を加呆てここに報告する.

$$
\text { 症例 }
$$

患者：68歳, 女性.

主訴：右季肋部痛, 背部痛, 湢吐.

現病歴：昭和59年 2 月右季肋部痛出現し近医受䛦. 胃炎の診断にて投薬を受けた。 6 月再び右季助部痛, 背部痛出現し，同時に嘔吐し近医入院精査. 肝腫瘍を 寲われて当センターに転院した。

既往歴：昭和 22 年虫垂切除術. 輸血歴, アルコール 歴なし。

家族歴：特記すべきことなし。

現症：身長 $147 \mathrm{~cm}$, 体重 $46 \mathrm{~kg}$, 血圧 $124 / 76 \mathrm{mmHg}$, 脈拍 $60 / \mathrm{m}$ 整.

体格 瘦せ型。栄養状態 良好. 眼䀫結膜 貧血な し. 眼球強膜 黄㾝なし. 胸部理学的所見に異常は認 められなかった。腹部所見では腹水なく, 肝脾は触知 せず, 腹部腫瘤は認められなかった。

入院時血液生化学所見：赤血球数 $348 \times 10^{4} / \mathrm{mm}^{3}$, 白 血球数 $3,500 / \mathrm{mm}^{3}$, 血小板数 $11 \times 10^{4} / \mathrm{mm}^{3}$, 総タンパ

$<1989$ 年 9 月 19 日受理>別刷請求先：山本 雅一 干113 文京区本駒込 3-18-22 東京都立駒込病院 外科
ク $6.3 \mathrm{~g} / \mathrm{dl}$, 総ビリルビン $1.3 \mathrm{mg} / \mathrm{dl}, \mathrm{GOT} 46 \mathrm{KU}, \mathrm{GPT}$ 27KU, alkaline phosphatase 15.1KAU, $\gamma$-glutamyl transpeptitase $102 \mathrm{mU} / \mathrm{ml}, \mathrm{LDH}$ 237WLU, B 型肝炎 ウイルス S 抗原陰性・抗体陽性， $\alpha$-fetoprotein (以下 AFP) $28 \mathrm{ng} / \mathrm{ml}$, carcinoembryonic antigen $3 \mathrm{ng} / \mathrm{ml}$, ICG 15分停膟率19\%, 便潜血 陽性.

腹部超音波検査：右後区域に門脈を背側から圧排す る形で不整な低ェコー領域を認め後区域胆管および門 脈の描出が不良になっていた。 またその部の肝表面側 に音響陰影を伴う高ェコー域があり肝内結石が疑われ た。 また, 肝表面に凹凸像を認め肝硬变と診断された。

血管造影：動脈造影にて末梢動脈の軽度の蛇行像が 指摘されたが, 明らかな動脈の不整像, 腫瘍濃染像は 認められなかった（Fig. 1)。

computed tomography（以下 CT)：右後区域に門 脈域に一致して不整な低吸収領域が認められた。門脈 が造影不良なため, 門脈内腫場栓が疑われた(Fig. 2).

術前経皮経肝的門脈造影: 末梢門脈の軽度の蛇行像 を指摘されたが，門脈枝に明らかな異常は認められな かった. しかし, 後区域門脈の領域は前区域之比較し 小さな領域であった（Fig. 3).

術前経皮経肝的胆道造影：右後区域胆管が描出され ず，胆管閉塞が疑われた（Fig. 4)。

以上の画像診断により肝硬変に併存した胆管癌, 肝 内結石症の診断にて 7 月 10 日開腹した. 
Fig. 1 Celiac angiogram shows no evidence of abnormality.

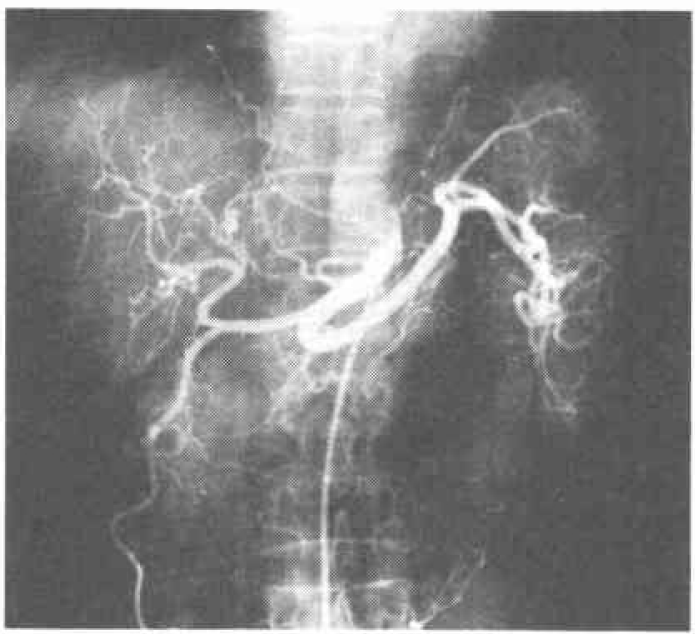

Fig. 2 CT scan of the abdomen shows irregular low density area in the posterior segment of the liver.

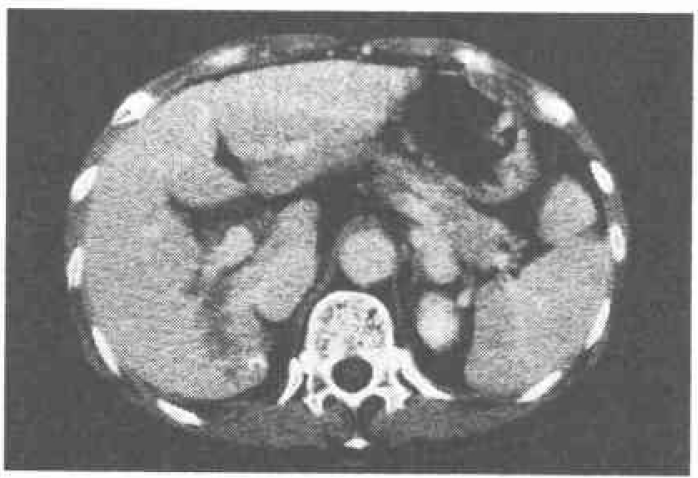

手術所見：上腹部逆 $\mathrm{T}$ 字切開にて開腹した. 腹水, 腹腔内リンパ節腫大は認められなかった。肝臓は両葉 とも萎縮し肝表面は小結節状で肝硬变と判断した。術 中胆管造影にて右後区域枝と考兄られる胆管内に隆起 状の欠損像が認められるため胆道鏡を施行した。また 胆道内には $5 \mathrm{~mm}$ 程度の黑色の柔らかい結石様物質が あり，これを摘出した。胆道鏡では，後区域胆管内に 不整に突出した腫瘍を認め，内腔は完全に閉塞してい た。肝門部での後区域グリソン枝の切断による肝表面 色調変化でみると, 後区域は萎縮して小さな領域であ り, 後区域切除, 総胆管切開 $\mathrm{T}$ 字管設置術を施行した。 な扮術中迅速組織診断にて結石様物質は肝細胞癌と凝 血壊死組織であった。
Fig. 3 Percutaneus transhepatic portogram shows no evidence of abnormality.

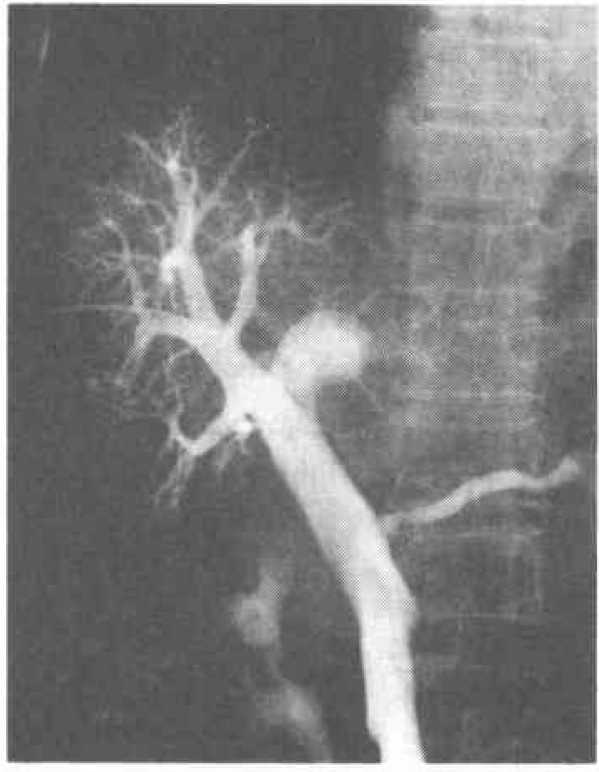

Fig. 4 Percutaneus transhepatic cholangiogram can not reveal the posterior branch of the intrahepatic bile duct.

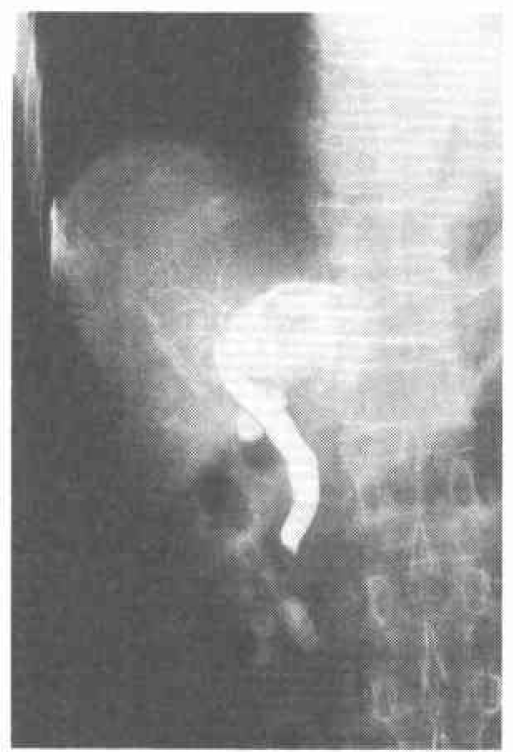

切除標本肉眼所見 (CT 断面での切割面)：後区域に 直径約 $1.0 \mathrm{~cm}$ の白色の腫瑒があり，その腫瘍から連続 して後区域胆管を充満するように腫瘍が伸び出してい た。非癌肝は肝硬変であった（Fig. 5). 
Fig. 5 Resected specimen reveals a small nodular tumor with remarkable protrusion into the intrahepatic bile duct.
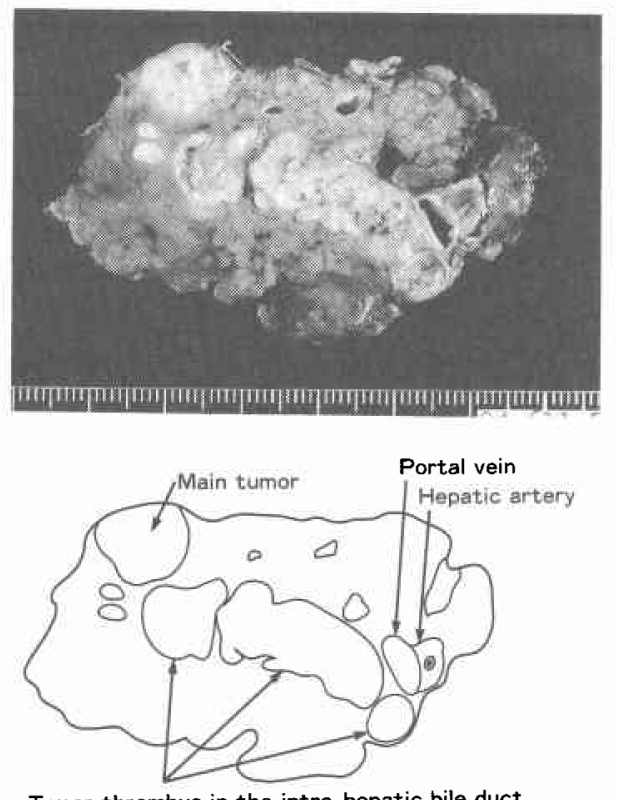

Tumor thrombus in the intra-hepatic bile duct

病理組織所見：主腫瘍と考えられる部には，厚い線 維組織の中に肝細胞癌 (trabecular pattern, Edomondoson II 型)があり，小石灰化巣も認められた。 また， 主腫瘍の周囲肝組織の一部が凝固壊死し, 萎縮した像 が認められた。主腫瘍に連続して, 胆管内を肝門部に 向かっての同様の腫瘍が充満していたが，門脈内に明 らかな浸潤は認められなかった。末梢の胆管壁は肥厚 し, 内腔は拡張し, また一部に胆管の増生像が認めら れた. 末梢胆管内の腫瘍最先端部には血栓を形成して いた。非癌肝は甲'型の肝硬变であった（Fig. 6).

術後経過：術後第30病日に退院, 以後外来にて経過 観察していた，術後 10 か月後の昭和60年 5 月, 外来腹 部超音波検査にて右前区域に直径 $2 \mathrm{~cm}$ 大の肝細胞癌 を認め, 局注療法(メタノール2ml, アドリアマイシン $5 \mathrm{mg}$ ）を施行した. その後 5 回局注療法を追加し, 腫汪 は直径約 $1.0 \mathrm{~cm}$ の不整な高ェコー領域となった。しか し, 昭和63年 6 月急速に増大する左外側区域の肝細胞 癌を認め, 肝動脈塞栓術 (アドリアマイシン $10 \mathrm{mg}, リ$ ピオドール $3 \mathrm{ml}$, ゼルフォーム細片)を施行し，その 2 週後の 7 月 12 日に, 肝左葉・尾状葉切除を施行した。 切除標本では, 門脈臍静脈部に門脈腫瘍栓を認める長 径 $10 \mathrm{~cm}$ の塊状型腫瘍であり, 病理組織学的所見では,
Fig. 6 Histological findings of the tumor show hepatocellular carcinoma (trabecular pattern, Edmondson II). (H-E stain, $\times 200$ )

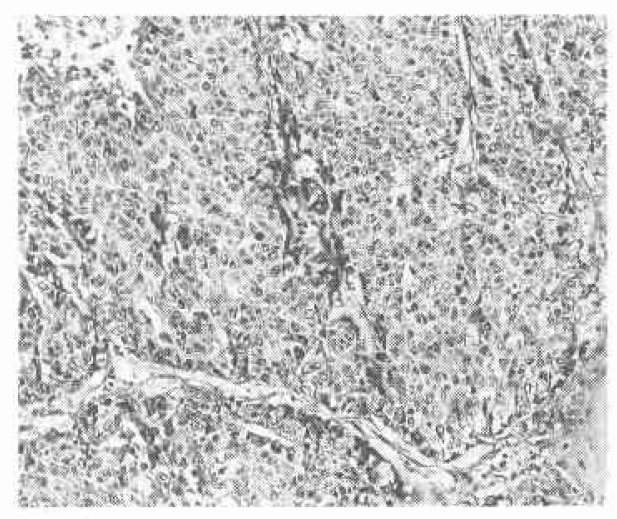

腫瘍の大部分は壊死に陥って和り, 辺縁の一部に索状 型, Edmondson II 型の肝細胞癌が認められた。 腫瘍内の末梢胆管内に腫瘍の浸潤像が認められた。再 切除後の経過は良好であり, 初回切除上り 4 年以上経 過した現在も社会復帰し，外来通院中である。

\section{考察}

肝細胞癌の胆管侵颤の頻度は剖検例では, 熊谷 ${ }^{1)}$ よると $7.6 \%$ と報告されているが, 臨床例, 特に手術例 で経験することは非常にまれであると思われる213.こ のような事実から，術前に正確な診断がなされること は少なく，胆管癌，肝内結石症の診断をうける場合が 多いとされている23). 臨休診断に扎いて血中 AFP 值 が著明に上昇している場合は，他の画像診断と合わせ れば診断を誤る可能性は少ないと考党られるが，本例 のようにAFP 值が低值あるいは陰性で, さらに主腫 瘍が小さいとさの診断は非常に難しいと考えられた。

Lin 5“が“icteric type”と分類したように, 臨床例 では大部分の症例が閉塞性黄㾝を呈している35).これ は胆管内発育腫瘍が肝内胆管から総胆管におよんでい ることが多いことからも明らかであり ${ }^{336)}$ ，しかも，胆 管内腫瘍の壊死により, 黄疸の消長がみられることも 特徴的であるとされている。しかし，本例のように肝 内の 1 区域だけの胆管内腫瘍栓の場合には, 黄疸が発 現しない可能性もあると考学られた。本例の主訴は疼 痛, 嘔吐であるが,これは腫煌の脱落壊死組織が結石 のように胆管末端に陷頓し，一時的に胆管内圧の上昇 した状態と思われる、閉塞性黄庭とともにこのよらな 結石様症状を呈することも, 胆管内発育腫滨の特徵で あると考えられた。 
肝細胞癌胆管内発育の機序として, 神代ら ${ }^{6)}$ は肝門 部の比較的大きな腫瘍から主胆管へ直接に浸潤するも のと, 門脈内腫瘍栓の隣接胆管内への伸展を述べ, 病 理形態学的に浸潤性の発育を呈する腫愊の重要性を指 摘している。また，日野ら7肝十二指腸間膜内リンパ 節に転移した後に，隣接する胆管内に進展する機序に ついても言及している。しかし，本例は肝表面近くに 存在した直径約 $1.0 \mathrm{~cm}$ の結節型肝細胞癌であり, 門脈 侵襲子認めず，胆管内発育腫瘍だけが目立つ特異な像 を呈していた，切除標本で検討すると，主腫湯周囲に は著明な線維組織があり, 周囲肝組織は凝固壊死に宿 り，萎縮した像を認めた。本例は肝細胞癌が直接胆管 内に浸潤した形態と考兄られるが，腫堭がなんらかの 原因で壊死の状態に陥り，この段階で周囲肝組織を巻 き込み, 胆管内に癌細胞が浸潤したものと考えられた。 またこのような病態により，小型の結節型肝細胞癌 であっても胆管内腫瘍発育をきたす可能性があると思 われた。

胆管内発育と切除後の再発に関して関連付けた報告 は現在のところみられていないが，血管唚襲を伴う大 型の浸潤型腫瘍が多いことからも再発率は高いことが 考えられる。ぬた，腫瘍は胆管壁への浸潤が少なく胆 管壁より剝離しやすいこと息，胆管内発育病巣は肝門

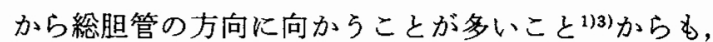
十二指腸側胆管内に泍落した腫瘍から再発病巣を形成 することは推測される。本例に括いては，胆管内腫瘍 から発育した再発病巣は見いだすことはできなかっ た。また，前区域病巣については標本がないことから 再発, 再度発癌の鑑別は困難と考兄られた。左葉外側 区域の肝細胞癌は，肝動脈塞栓術の影響もあり十分な 検索はできなかったが, 初回肝細胞癌と細胞異型度お よび組織型が一致していること，胆管侵襲を同様に伴 らことなどから，いわゆる残肝再発ではないかと考克 ている.

予後に関しては, 胆管内発育は進行癌での 1 症状と
考えられているように, 非常に不良とされている33.し かし，本例は再発をきたしたものの，再発病巣に対し て積極的に対処した結果, 初回切除後 4 年以上の現在 も健在であり社会復㷌している。このことからす胆管 侵襲は癌末期の病態ではなく，腫瘍の病態によって呈 するひとつの所見であり，腫瘍の進展形態からも系統 的なグリソン鞘処理による肝切除采が重要であると思 われた。

\section{おわりに}

結石様庭状にて発現し，残肝再発に対し積極的に対 処することにより，術後 4 年以上の現在も社会復帰し ている胆管内発育を呈した小結節型肝細胞癌の 1 切除 例について報告した。

\section{文 献}

1）熊谷保也：原発性肝癌の病理形態学的研究肝細 胞癌の胆道内発育について。肝臓 $20: 157-163$, 1979

2）浜崎啓介，三村 久，戸田佐登志汪か：胆管内発育 型細小肝細胞癌の 1 切除例。胆道 $2: 539-546$, 1988

3）田口久雄, 荻野隆章, 宮田昭海深か：胆道内発育を した肝細胞癌の 2 例と本邦報告例の臨床的解析. 日消病会誌 $80: 2259-2268,1983$

4) Lin $T$, Chen $K$, Chen $Y$ et al : Icteric type of hepatoma. Med Chir Dig 4:267-270, 1975

5）才津秀樹，小林重矩，浜崎 恵ほか：胆道内発型 肝細胞癌一自験 2 例を含む本邦報告79例の臨床的 検討一。消外会誌 $15 ： 1572-1578,1982$

6）神代正道, 川野芳郎, 白井文夫活か：肝細胞癌の胆 管内発育についてーその臨床的, 病理学的意義一。 最新医 $36: 1223-1228,1981$

7）日野真一,五十峲正彦, 隆 元英ほか：閉塞性黄疸 で発症した肝細胞癌の 1 剖検例. 肝臟 $25: 94$ $-103,1984$

8）高崎 健：肝硬变併存肝癌の切除術式の選択基準 一安全性, 根治性を考慮に入れた切除範囲の調節 とそれに必要な手術手技の工夫一日消外会誌 $19: 1881-1889,1986$ 